Saul Newman. He teaches Political Theory at Goldsmiths College, UCL, where is Head of the Department of Politics. His main topics are contemporary political and social theory, particularly from the Continental tradition, as well as radical political thought. His main publications are: Anarchism Today (co-edited with Carl Levy) Routledge, 2014; Agamben and the Politics of Human Rights: Statelessness, Images, Violence_(co-authored with John Lechte), Edinburgh University Press, 2013; Max Stirner, Palgrave Macmillan, 2011; The Politics of Postanarchism, Edinburgh University Press, 2010; Unstable Universalities: Poststructuralism and Radical Politics, Manchester University Press, 2007; Power and Politics in Poststructuralist Thought: New Theories of the Political, Routledge, 2005; From Bakunin to Lacan: Anti-authoritarianism and the Dislocation of Power, Lanham, M.D., Lexington Books, 2001.

Contact: s.newman@gold.ac.uk 


\section{THE QUESTION OF FREEDOM IN FOUCAULT AND LA BOETIE}

\section{Saul Newman}

Goldsmiths College, UCL

Reception date April 10 ${ }^{\text {th }}$ 2015; Acceptance date May 11 ${ }^{\text {th }} 2015$. This article is the result of research activities held at the Department of Politics (Goldsmiths College, UCL).

\section{Abstract}

This paper argues that the key to understanding question of freedom in Foucault lies in the problematic of 'voluntary servitude', whose enigmatic condition was first explored in the sixteenth century by Étienne de La Boétie. The essay, De la Servitude Volontaire, comes to grips with what is perhaps the most intractable enigmas in politics: why people freely submit to their own domination.

Starting from the idea that freedom, so far from signifying the absence of power, is only intelligible and realizable through its relation to power, the author shows that Foucault is concerned with that which binds us to power at the level of our subjectivities; and, with the other side of this, how we are able to resist, contest and problematize this attachment, and how we are able to engage in practices of self-constitution which are, for him, 'practices of freedom'.

\section{Keywords}

Practices of freedom, power, "voluntary servitude", counter-conducts.

\section{Resumen}

Para lograr entender la cuestión de la libertad en Foucault, es necesario analizar la problemática de la "servidumbre voluntaria", cuya enigmática condición fue examinada primero por Étienne de La Boétie. Su ensayo, titulado De la Servitude Volontaire, discute el enigma de la política quizá más complejo: ¿por qué los hombres se someten al dominio? 
A partir de la idea de que la libertad, lejos de significar ausencia de poder, solo se puede entender y realizar por medio de su relación con el mismo poder, el autor pretende demostrar que Foucault, por un lado, se interesa por lo que nos relaciona con el poder respecto de los varios niveles de nuestra subjetivación; por otro lado, por como somos capaces de resistir, poner en duda y problematizar este vínculo y de comprometernos con prácticas de auto-constitución que, para él, son "prácticas de libertad".

\section{Palabras clave}

Prácticas de libertad, poder, "servidumbre voluntaria", contraconductas.

\section{Introduction}

One of the more seemingly problematic areas of Foucault's thought is on the question of freedom. What place does freedom have in Foucault's thought; how might it be understood? If 'power is everywhere', if it is coextensive with all social relations, if it is to be found in everyday interactions between individuals, then what room is left for freedom? How can spaces for freedom be reconciled with the ubiquity of power relations, with the apparent omnipresence of disciplinary constraints, forms of power/knowledge which construct individuals as subjects, and with governmental rationalities aimed at normalizing behavior? Foucault sees freedom as a kind of 'game' played with power, as a series of strategic moves that can take place within certain limits set by power. However, if this is the case, it would seem to offer only limited opportunities for freedom. Freedom, and the possibilities of resisting power, would seem to be produced by, or at least realized through, the operation of power itself, and are therefore always constrained by it. ${ }^{1}$

1. This, at least, has been the charge made by many of Foucault's critics - from Marxists and critical theorists, to communitarians and liberals. According to these critical voices, Foucault undermines any real possibility for freedom. It is claimed that he leaves us at a dead-end politically; that his dystopian, pessimistic thinking locks us into disciplinary cages from which there is no possibility of escape. No wonder, it is claimed, Foucault turned in his later work to questions of ethics and the care of the self, which was seen by some as a further retreat away from politics into an individualistic and nihilistic aesthetics of self-fashioning, or by others, as an acknowledgement that his genealogical investigations had reached a certain limit or impasse beyond which he had to go if there was to be any conception of ethics or freedom at all. For critiques of Foucault along such lines, see for example N. Fraser, "Foucault on Modern Power; Empirical Insights and Normative Confusions", in Praxis International, 1(3), 1981, pp. 272-87; C. Taylor, "Foucault on Freedom and Truth", in Political Theory, 12(2), 1984, pp. 152-183; J. Habermas, "Modernity versus Postmodernity", in New German Critique, 22 (Winter), 1981, pp. 3-14; M. Walzer, "The Politics of Michel Foucault", in D.C. Hoy (ed.), Foucault: a Critical Reader, Wiley-Blackwell, Oxford (UK)-Cambridge (Mass.), 1991, pp. 51-68. 
I want to argue, against this commonplace view, that Foucault is a thinker who is passionately — we could say ecstatically — committed to freedom. But how exactly should freedom be understood in Foucault's thinking? Clearly, for Foucault, freedom cannot be seen in terms of the standard liberal conception of negative freedom, or freedom from constraint. If we take the idea that freedom, so far from signifying the absence of power and constraint, is only intelligible and realizable through its relation to power, then the notion of freedom from power simply has no meaning for Foucault. Freedom and power are not polar opposites and they do not exist in a zero-sum game such that the absence of one is the condition for the presence of other. ${ }^{2}$

Power and freedom have to be seen as existing in a relationship of mutual incitement and provocation, an agonistic game of strategies and wills, where each opposes the other but is also the condition for the other's very existence. However, it is also clear that Foucault's understanding of freedom cannot fit into the category of positive freedom which refers to living and acting according to one's higher rational and moral capacities - that is, being autonomous in a Kantian or Rousseauian sense. While Isaiah Berlin's formula for positive freedom — "being his own master" 3 — does indeed resonate with Foucault, if understood in a different way that I shall elaborate later, the sense in which Berlin himself intends it, as a certain standard of freedom which is said to be a reflection of our higher self, which the individual is expected, 'forced' even, to live up to, could not be any further from Foucault's sensibilities. While, as I shall argue later, there is some sense in which, for Foucault, freedom is only realizable through a kind of self-disciplining, this is not the same as setting up some universal standard or norm of freedom that we have to be disciplined into achieving. For Foucault, that is exactly what liberal freedom is all about.

So we can say that, for Foucault, freedom is not a property; nor is it a stable situation or state that one can be in - one can never claim to be finally free, either externally or internally. Rather, freedom must be constantly put to the test agonistically. To better appreciate the significance of freedom in Foucault's thinking, we therefore have to put to one side both liberal and communitarian understandings, as well as the meta-narrative of the emancipation of humanity. What would this be, after all, but the imposition of

\footnotetext{
2. As Foucault says: "There is not a face-to-face confrontation of power and freedom as mutually exclusive facts (freedom disappearing everywhere power is exercised) but a much more complicated interplay. In this game, freedom may well appear as the condition for the exercise of power (at the same time its precondition, since freedom must exist for power to be exerted, and also its permanent support, since without the possibility of recalcitrance power would be equivalent to a physical determination)”. M. Foucault, “The Subject and Power”, in J.D. Faubion (ed.), Power: Essential Works of Foucault 1954-1984, vol. 3, Penguin, London, 2002, p. 342.

3. I. Berlin, Two Concepts of Liberty, Clarendon Press, Oxford, 1958, p. 8.
} 
another form of power, another kind of social order in the very name of freedom?

What I want to argue here is that the key to understanding question of freedom in Foucault lies in the problematic of 'voluntary servitude', whose enigmatic condition was first explored in the sixteenth century by Étienne de La Boétie, whose essay - De la Servitude Volontaire - comes to grips with what is perhaps the most intractable enigmas in politics: why people freely submit to their own domination. What I want to suggest is that the same line of questioning, the same critical impulse, inspires Foucault; specifically, the investigation of the micro-political relationship between the subject and power, which, as we have seen, is never one of simple opposition but rather of mutual constitution and intensification. Foucault is concerned, after all, with that which binds us to power at the level of our subjectivities; and, with the other side of this, how we are able to resist, contest and problematize this attachment, and how we are able to engage in practices of self-constitution which are, for him, "practices of freedom." ${ }^{4}$ Both La Boétie and Foucault's thought can be read as a profound meditation — and I intend this to invoke something of the spiritual sense of the word — on the possibilities of freedom and on our potential for voluntary inservitude.

\section{Foucault's Enlightenment}

To trace this resonance between the two thinkers, I want to start by considering a lecture that Foucault gave at the Sorbonne in May 1978, called "What is Critique?" Here Foucault explores the emergence in Western thought, dating roughly from the fifteenth and sixteenth centuries (crucially we should note that this is the time in which La Boétie is writing) of a certain "critical attitude", which, importantly, predates the Kantian enterprise. ${ }^{5}$ For Foucault, a way of explaining the emergence of this critical attitude is as a reaction to what he calls the governmentalization of Western European societies during this period: the art of governing which characterized the Christian pastorate, and which during the Middle Ages had been confined to religious and monastic institutions, now becomes the general, ubiquitous rationality of society itself, pervading matters of family, social, economic and political life. As Foucault says, the fundamental question that

\footnotetext{
4. M. Foucault, “The Ethics of the Concern for Self as a Practice of Freedom", in P. Rabinow (ed.), Ethics: Essential Works of Foucault 1954-1984, vol. 1, Penguin, London, 2000, pp. 281-301.

5. See M. Foucault, "What is Critique?", in J. Schmidt (ed.), What is Enlightenment? Eighteenth Century Answers and Twentieth Century Questions, University of California Press, Berkeley, 1996, pp. 382-398.
} 
emerges during this period is: how to govern ${ }^{6}$ It is important, then, to look more closely at the Christian pastorate because this forms the basis of the governmental rationality that persists even into our liberal biopolitical modernity. The key element of the pastorate, which Foucault explores in various places - particularly in his lectures taking place at the same time at the Collège de France, and now published as Security, Territory Population - is the notion of obedience: the shepherd-flock relationship is one of absolute obedience or servitude. ${ }^{7}$ This relation of submission takes place at an individual level; it is a relationship between the shepherd and the individual members of his flock. The shepherd governs each and all, singularly and collectively, 'omnes et singulatim.' What is cherished in this relationship is obedience as the absence or relinquishment of willpower, particularly of the will over oneself; in Greek, apatheia. This is important and I will return to it later, for both Foucault and La Boétie are concerned with the problem of the will.

However, such pastoral relations of obedience are always accompanied by the possibility of disobedience - for instance, the religious heresies of the Middle Ages, which could be seen in terms of 'counter-conducts' (for example, asceticism and other practices of self-discipline) which challenged the pastoral power of the Church to govern the actions, lives and souls of others in the interests of their salvation. We might say, then, that if power is the conduct of conduct, then 'counter-conduct' is the reversal or disruption of this relationship — the possibility of acting and behaving differently. A reversal whose potential is ever-present in, and indeed presupposed by, any relation of power.

It is precisely this spirit of disobedience, of 'counter-conduct', which, as Foucault argues, re-emerges in the fifteenth and sixteenth centuries in response to the explosion of governmental practices and discourses. Thus, alongside the question of how to govern arises the opposing question, 'how not to be governed?' - a question that guides and moves the spirit of critique. But this is a specific problematic: it is how not to be governed in specific ways, in the name of specific rationalities or principles, or through specific methods; "how not to be governed like that." We see the appearance or re-appearance, then, of a glorious art: the art of not being governed. While, as Foucault goes on to say, doctrines of natural law and natural rights served during this period as the basis of this

6. See ibid., p. 384 .

7. See M. Foucault, Security, Territory, Population: Lectures at the Collège de France 1977-78, edited by M. Senellart, Palgrave Macmillan, Basingstoke, 2007, p. 177.

8. See M. Foucault, “The Ethics of the Concern for Self as a Practice of Freedom”, pp. 281-301.

9. M. Foucault, “What is Critique?", p. 384. 
critique of government ${ }^{10}$ — opposing the absolute power of the sovereign with some notion of juridical limits - the art of not being governed, at least as we might think about it today, suggests that rather than relying on any natural or a-historical bedrock of freedom as the counter-point to power, freedom is instead something to be learnt, practiced, a conscious style of living, something that is contingent to specific situations and which is continually elaborated.

To continue in this critical spirit — which also essentially motivates Kant's Aufklärung — Foucault seeks to inaugurate what he calls a "historicophilosophical" mode of enquiry ${ }^{11}$ — perhaps it would be more familiar to us as genealogy. This mode of enquiry proposes a historicisation of ideas, such that a critical reflection on and interrogation of the legitimacy of modern forms of knowledge and regimes of truth are made possible; this is through what Foucault terms their 'eventialization' ["événementialisation"], ${ }^{12}$ which is a way of unmasking the relationship between power and knowledge, of revealing the multiple coercions involved in a system of knowledge becoming hegemonic. The question asked here - and it is a crucial one — is not so much how a system of knowledge is forced on us in an overt sense, but rather, how and under what conditions it becomes acceptable and normalized. In other words, how do we come to accept our subjection to a particular regime of truth and the forms of power that go along with it? What must be investigated, in other words, is the mechanism by which we voluntarily subject ourselves to a specific mode of power. What is being highlighted is a sort of subjective threshold through which the subject binds himself to various forms of power, and that threshold is a certain regime of truth which we internalize.

Importantly, the fact that a particular regime of power/knowledge/truth becomes acceptable to us does not mean that this process was inevitable, or that it revealed to us some originary right that made it legitimate. On the contrary, its emergence is entirely contingent. ${ }^{13}$ It is as if a system of power and knowledge suddenly arises, and the violence of its imposition is at the same time indistinguishable from our free acceptance of it — they are simply two sides of the same process of subjectification. But this contingent dimension of rupture, and this rejection of the notion of inevitability, means that any system of power/knowledge that emerges is always tenuous. They are merely singularities without an essence, and as such they can always be thought otherwise and

10. See ibid., p. 385 .

11. See ibid., pp. 319-392.

12. Ibid., p. 393.

13. As Foucault points out, "bringing out the conditions of acceptability of a system and following the lines of rupture that mark its emergence are two correlative operations" (ibid., p. 395). 
undone: "one has to deal with something whose stability, whose rooting, whose foundation is never such that one cannot in one way or another, if not think its disappearance, at least mark that through which and that from which its disappearance is possible."14 Every system of power is always fragile and haunted by the prospect of its own reversal and disappearance. So, we should not think of power in terms of mastery or domination, but rather as an unstable, impermanent set of relations and interactions. To put it quite simply, power has to be thought of as an event rather than as a transcendental reality, and as such, it is an event that can be reversed. Foucault asks: "And if it is necessary to pose the question of knowledge [connaissance] in its relation to domination, it would be first and foremost on the basis of a certain decisive will not to be governed." 15 Thus, for Foucault,

\begin{abstract}
If governmentalization is really this movement concerned with subjugating individuals in the very reality of a social practice by mechanisms of power that appeal to a truth, I will say that critique is the movement through which the subject gives itself the right to question truth concerning its power effects and to question power about its discourses of truth. Critique will be the art of voluntary inservitude, of reflective indocility. ${ }^{16}$
\end{abstract}

This phrase - "critique will be the art of voluntary inservitude" — opens up a completely different dimension in Foucault. So far from being the one who locks us up into disciplinary cages, the Foucault that emerges here is one who asserts the primacy of freedom, indocility, inservitude, the refusal to obey. We must grasp the astounding insight offered to us here, and appreciate its genuinely radical dimension. Foucault is saying, essentially, that all systems of power are not only fragile, unstable — they are, as he says, events without definitive origin, essence or transcendental unity or legitimacy - but indeed, can only emerge and become hegemonic through our free acceptance of them. Foucault is not proposing any notion here of ideological false consciousness. What he is saying is that systems of power/knowledge can only operate through a subjective threshold, in which the violence of its coercion becomes indistinguishable from our voluntary acceptance of it. But what does this really mean? It means that freedom — that is, the ability to think, live and act otherwise — is the ontological basis of all 
power. We have to be able to hear the murmur of freedom, of a yet unrealized yet always potentially realizable freedom that speaks incessantly through the fissures of power; we have to be attuned to its voice lest it be drowned out by power's cogs and machinery. Rather than power being the secret of freedom, as Foucault has so often been interpreted as saying, freedom is the secret of power. And this startling revelation - the ontological primacy of freedom, whereby every system of power/knowledge depends on our will, our acceptance - means that the undoing and reversal of this system is equally a matter of will, of decision, of free volition. Just as we will our own submission to particular forms of power, so we can will our own release from them. That is why Foucault refers to a "decisive will to not be governed". Is this not an affirmation of freedom in its truest form? Not freedom as some abstract goal to be achieved, or as a program of liberation and social organization to be handed to us, but the freedom that we always already have. It is simply a matter of recalling this fact, of reminding ourselves that the power that seems to engulf us really depends on our acquiescence, our consent, and that all that is required to overturn this relationship of domination is a refusal of our servitude, a willing of our own freedom, a willingness to not be governed. Freedom, then, is simply our voluntary servitude reversed, our voluntary inservitude.

\section{La Boétie's Problem}

Yet, to really appreciate the significance of this insight, we need to understand more precisely the problematic of voluntary servitude itself. And this requires an encounter with the figure who forms the enigmatic background to Foucault's thinking, who is silently but reverentially intoned behind his words.

Étienne de La Boétie, who was born in Sarlat in France in 1530, and who, if it were not for the Discours de la Servitude Volontaire (also known as the Contre'Un or Anti-One, and written probably in 1548 when he was only 18) would only be known as the friend and confidant of Michel de Montaigne, asked a simple, yet scandalous, question: why do men obey?

For the present I should like merely to understand how it happens that so many men, so many villages, so many cities, so many nations, sometimes suffer under a single tyrant who has no other power than the power they give him; who is able to harm them only to the extent to which they have the willingness to bear with 
him; who could do them absolutely no injury unless they preferred to put up with him rather than contradict him. Surely a striking situation! Yet it is so common that one must grieve the more and wonder the less at the spectacle of a million men serving in wretchedness, their necks under the yoke, not constrained by a greater multitude than they, but simply, it would seem, delighted and charmed by the name of one man alone whose power they need not fear, for he is evidently the one person whose qualities they cannot admire because of his inhumanity and brutality toward them... What monstrous vice, then, is this which does not even deserve to be called cowardice, a vice for which no term can be found vile enough, which nature herself disavows and our tongues refuse to name? ${ }^{17}$

We can see how this willing submission to domination, this voluntary servitude to the will of a tyrant — who is simply a creation of the abandonment of our own will and our own power - constitutes a genuine mystery for La Boétie. He is dumfounded in the face of it, and struggles to name it. It must not be confused with cowardice, he says, which, while despicable is in some ways understandable. Here the power imbalance between the masses and the tyrant is so great that cowardice simply cannot account for the former's acquiescence to the latter; the people have the power, and yet they choose, freely, voluntarily, to give it up to one man who lords it over them, and yet who is essentially their creation, and who could be toppled without lifting a finger. How can this be explained? Like a doctor unable to diagnose his patient's condition, La Boétie struggles to identify and account for this moral sickness. There must be some sort of misdirection or aberration of the will: people, who normally, naturally desire freedom, for some reason choose to give up this freedom and to will their own servitude.

Freedom is our natural condition; man is a being intended for freedom, and for the enjoyment of the natural bonds of companionship and equality, not the artificial bonds of power. Servitude is so far removed from our nature that even animals resist the slightest constraint on their freedom. To be subjected to power is therefore unnatural, and to will our own subjection to power is even more unaccountable. In this sense, La Boétie might be regarded as the anti-Hobbes. For Hobbes, the freedom that we suffer in the state of nature is unnatural to us in the sense that we cannot live in peace and security; and thus the desire to submit to absolute sovereign power - even though it is a human

17. É. La Boétie, The Politics of Obedience: the Discourse of Voluntary Servitude, Ludwig von Mises Institute, Auburn (Al), 2008, pp. 40-43. All quotes from La Boétie henceforth are from the Harry Kurtz translation available at: http://www. constitution.org/la_boetie/serv_vol.htm. 
artifice rather than a natural authority — is itself utterly natural and rational. ${ }^{18}$ For La Boétie, this whole rationalization of submission is reversed: we enjoy the freedom and equality, indeed, the plurality and singularity that nature endows us with; and then, for some reason, on account of some misfortune of history — which La Boétie does not or perhaps cannot explain - we give it up, and have suffered the caprices of power and the torments of servitude ever since. One whole century before the shadow of Leviathan loomed up over our horizon, La Boétie had already disturbed its foundations by revealing the freedom that lay behind it, the freedom which Hobbes tried to make us forget.

Our fall into servitude has something to do with apathy; a kind of moral languor that comes over us so that we no longer desire freedom and independence. But at the same time, La Boétie is eager to stress that our servitude is active rather than passive; our domination is something that we willingly participate in; the cords that bind us we renew and strengthen daily: "You weaken yourselves in order to make him the stronger and the mightier to hold you in check." 19

How does La Boétie attempt to account for what is essentially unaccountable? He proposes three factors that might explain this lamentable condition that we find ourselves in. Firstly, he says, men become habituated into servitude such that they forget that they were ever free; obedience and docility become a matter of habit, a "habituation to subjection." ${ }^{20}$ As he puts it, "let us therefore admit that all those things to which he is trained and accustomed seem natural to man and that only that is truly native to him which he receives with his primitive, untrained individuality." ${ }^{21}$ Perhaps we are not very far here from Foucault's "docile bodies" — the bodies and behaviors relentlessly trained, molded and shaped in the disciplinary regimes of modernity. To what extent does this rely on a voluntary servitude, as described by La Boétie, rather than outright violence and coercion? To what extent would disciplinary power be possible without the subjectification of the subject so that he or she actively desires and willingly participates in his or her own disciplining and normalization?

Secondly, La Boétie refers to the ways that power distracts us, dazzles us, seduces us with its gaudy show, with its spectacles and rituals. ${ }^{22}$ Thirdly, La Boétie shows how power constructs for itself a hierarchy of relations in which the tyrant's place is sustained by intricate networks and relations of dependency. Our submission and obedience are

\footnotetext{
18. See T. Hobbes, Leviathan (1651), edited by C. B Macpherson, Penguin, London, 1981.

19. É. La Boétie, The Politics of Obedience: the Discourse of Voluntary Servitude, pp. 46-47.

20. Ibid., p. 54.

21. Ibid., p. 59.

22. See ibid., pp. 63-64.
} 
assured — bought cheaply La Boétie would say — by payoffs that we receive from those immediately above us; we submit to the power of another in return for our own little place in the great pyramid of power that we ourselves have constructed. ${ }^{23}$

However, La Boétie's explanations for our condition of servitude — and to some extent they are inadequate - are perhaps less important than the implications of his actual diagnosis of the problem of our voluntary servitude, this enigma at the heart of all political domination. But it all depends on what we take from this. If we interpret La Boétie as simply saying that man will always, when he gets half the chance, submit to power and cut his own throat, then the notion of voluntary servitude does not get us very far, and may even give rise to a certain conservatism, which says that men are born to submit. But nothing could be further, I would argue, from La Boétie's intentions, especially when he says that freedom rather than servitude is our natural condition. Therefore, the way I propose we read his great work is in an emancipatory sense, as a call to freedom, as a way of waking us up, arousing us from our enfeebled, servile state; perhaps in the same way that Foucault reads Kant's Aufklärung, as a way of rousing humanity out of a state of immaturity. La Boétie does this by confronting us with a truth so astounding that it has the power, even today — if only we would see it — to shake the foundations of political authority to their core. If we have freely chosen servitude, if we willingly participate in our own domination without the need for coercion, then this means that all power - even as it appears to bear down upon us - is essentially an illusion, one of our own making. If, in other words, we have created the tyrant in our act of submission to him, this means that the tyrant has no real power; the power he has over us is only our power in an alienated form; the chains that bind us are only possible through an abrogation, a giving up, of our own power over ourselves. As he decisively puts it, "He who thus domineers over you has only two eyes, only two hands, only one body, no more than is possessed by the least man among the infinite numbers dwelling in your cities; he has indeed nothing more than the power that you confer upon him to destroy you." 24

All power is therefore fragile, and is only possible by our continuing submission, the continual offering of ourselves to power. All we must do is to see through the veils of power, to see its essential weakness, its emptiness and impotence. All we must do if we want to free ourselves from the tyrant is to simply take back our power - or, even more

23. "The consequence of all this is fatal indeed. And whoever is pleased to unwind the skein will observe that not the six thousand but a hundred thousand, and even millions, cling to the tyrant by this cord to which they are tied" (ibid., p. 72). 24. Ibid., p. 46. 
simply, to stop giving ourselves up to him, to stop rendering our power to him. It is not even a question of overthrowing the tyrant, but simply to stop empowering him and instead to empower ourselves, upon which the tyrant will fall of his own accord - the spell of domination will be broken. ${ }^{25}$

The pedestal of power is one that we have erected through our continual submission; it is very easily pulled away by our refusal to submit. That all power depends on our power — this is something we have forgotten. La Boétie wants people to recall their own power, or rather to recognize that they had the power all along, they just did not know it. La Boétie offers us no revolutionary programs to follow - none are needed; he simply wants us to emancipate ourselves, to emancipate ourselves from our own servitude. It is merely a matter of the will, volition, of "willing to be free", as he puts it. ${ }^{26}$ La Boétie's text thus serves to remind us of our own will — how we lost it, and how we can regain it. Is there not a profound connection here with Foucault's "decisive will not to be governed", which for him is the basis of all critique? The other side of voluntary servitude is therefore voluntary inservitude; the other side to power is freedom. The Discours s, like Foucault's work, an ethical meditation on freedom and its possibilities. Just as La Boétie considers the power of the tyrant to be an illusion, Foucault tells us that there is no such thing as Power with a capital $\mathrm{P}$, that power has no essence, that it is not a substance but a relation, not a property but an intensity, and that even in the seemingly direst conditions of oppression there is always the possibility of resistance, and therefore of freedom. To see power in this way — for both thinkers - is to in a sense strip away its abstractions, and to reveal the secret of freedom that it founded upon; it is not a negation of freedom but a joyous affirmation of it.

\section{Freedom and Discipline}

Of course, unlike La Boétie, Foucault would not trace voluntary servitude to one obscure but fateful historical moment, to a fall from our original state of freedom; rather, there has only been self-subjection in specific ways to specific regimes of power.

25. "Obviously there is no need of fighting to overcome this single tyrant, for he is automatically defeated if the country refuses consent to its own enslavement: it is not necessary to deprive him of anything, but simply to give him nothing; there is no need that the country make an effort to do anything for itself provided it does nothing against itself. It is therefore the inhabitants themselves who permit, or, rather, bring about, their own subjection, since by ceasing to submit they would put an end to their servitude..." (ibid., p. 44).

26. See ibid., p. 47. 
Nevertheless, the fundamental insight is the same: all forms of power, no matter how they are historically constituted, depend at some level on our willing acquiescence. How else could power arise? Voluntary servitude is the secret that underlies all the micro-disciplines and coercions, the institutional discourses, the regimes of surveillance, the vast carceral archipelago charted by Foucault. La Boétie's text, I believe, is the great key that allows us to unlock the eternal mystery of power; it shows us that power cannot exist without our own subjection to it. It sheds light on the threshold of subjectification that Foucault saw as the underside of any power relationship: why does the homosexual or madman attach himself to these institutionalized identities; why does the factory worker allow himself to be trained so that he becomes an appendage of the machine; why do we engage in rituals of confession that bind us to regimes of truth; why do we so earnestly seek out our truth in the codes of power? What is the hook, the clasp, the element that seduces us, that draws us in to this game of power?

Yet, as I have said, the other side to this willful docility is willful indocility, as La Boétie and Foucault so feverishly affirm. So, briefly, I think we can relate this problematic of 'voluntary servitude/voluntary inservitude' to two key aspects of Foucault's thought. I have already spoken about his notion of 'eventialization', and his general genealogical approach, which allows us to see that the structures of power, knowledge and truth which surround us have, in a sense, no essence, no transcendental legitimacy, and therefore no inevitability; they are ultimately contingent, fragile, depending on our willing submission to them. And this means that alternatives are always possible, that we are not condemned to the current arrangements. However, I want to explore briefly the relationship between power and the subject, and the way that - through the process of subjectification - a truth about ourselves is constructed for us such that we identify with it and allow ourselves to be governed in particular ways; yet this also provides us with the means to resist this power. The subjectified subject is one who is always capable of resistance, and therefore of freedom; the subjectivity that power creates for us, is also the material from which we can resist power and from which we can fashion for ourselves new ways of being. This means that the process of subjectification is always double-sided, unstable, unpredictable and reversible. While we are subjectified by power-truth, we are not determined by it, and there is always this excess, this element of unpredictable freedom which, while generated by power, is never confined by it, and which always has the potential to refuse, resist and reverse the actual form of our subjectification. 
A subsequent, related, point concerns the relationship between freedom and discipline. Contrary to the liberal model of negative freedom, which would see freedom and discipline as completely irreconcilable, perhaps we can see them as mutually dependent and constitutive. ${ }^{27}$ We have seen how the action of disciplinary power produces the capacities for both subjection, but also agency and therefore freedom. But what Foucault was interested in, as we can see in his later work on ethics, ascesis and the care of the self, was the ways by which people, in certain historical periods and within specific cultural settings, particularly in Greek and Roman antiquity, have actually sought to discipline themselves, to impose upon themselves, through various means - meditation, self-denial, ethical interrogation - a kind of discipline that would allow them to be free. While these forms of discipline might be a reflection of the cultural forms that existed at the time - so we are in other words not talking about complete autonomy here - they were nevertheless much more autonomous precisely because they were self-imposed, than the more institutionalized (religious, psychiatric, medical) modes and practices of discipline that emerged later with the Christian pastorate and have continued into modernity. Foucault refers then to "an exercise of the self on the self by which one attempts to transform oneself, and to attain to a certain mode of being." ${ }^{28}$ Foucault, furthermore, sees this process of self-disciplining, self-fashioning as an ethical practice, which is always related to the practice of freedom: "For what is ethics if not a practice of freedom, the conscious practice of freedom?" ${ }^{29}$ In other words, freedom is not a permanent state that one achieves, but an ongoing project or series of practices by which one constitutes oneself in alternative ways.

But how does this practice of self-disciplining, or self-mastery, intensify freedom, and why should this be seen as an ethical practice (as opposed to simply aesthetic, as some have argued)? The various practices associated with what Foucault calls "ascesis" were intended to achieve some sort of mastery over oneself such that one would not be so susceptible to being disciplined and governed by others: there is the recognition that, as Richard Flathman shows, within oneself there are tendencies, desires and dependencies that make one more susceptible to the power of others. ${ }^{30}$ La Boétie would see this as the tendency towards voluntary servitude. Thus, "ascesis" involves forms of

27. As Richard Flathman argues in his discussion of Foucault, without discipline, there is no agency and therefore no possibility of freedom. Also, disciplinary limits must be present for freedom to be tested and measured against, agonistically. See R.E. Flathman, Freedom and its Conditions: Discipline, Autonomy, and Resistance, Routledge, New York, 2003.

28. M. Foucault, “The Ethics of the Concern for Self as a Practice of Freedom”, p. 282.

29. Ibid., p. 284.

30. See R.E. Flathman, Freedom and its Conditions: Discipline, Autonomy, and Resistance. 
self-discipline designed to control and master such tendencies, in the interests of one's freedom. As Foucault puts it: "Concern for the self and care of the self were required for right conduct and the proper practice of freedom, in order to know oneself... as well as to form oneself, to surpass oneself, to master the appetites that threaten to overwhelm one." 31

This project of freedom through self-mastery is thus an ethical practice: "Freedom is the ontological condition of ethics. But ethics is also the considered form that freedom takes when it is informed by reflection." ${ }^{32}$ It is ethical because it not only concerns oneself but how one relates to others. For the Greeks, the desire to dominate others, to exert excessive power over them, is actually an indication that one is not master of oneself; one has become intoxicated with one's own appetite for power, an appetite or desire which has taken over all others within the individual. It is a sign of weakness rather than strength: as Rousseau understood, if one desires to dominate others, one is much more likely to be dominated by others. ${ }^{33}$ One enters the dangerous game of tyranny only at one's own cost. Did not La Boétie also perceive this essential weakness of the tyrant? And did he not also warn that those who play the game of power, those who allow themselves to enter the tyrant's great pyramid, in the hope of rewards and favors, or so they can exert power over someone below them, put themselves at great risk? So, we have here, with the practices of freedom through self-mastery, also an ethics (and I would say perhaps a politics) of non-domination.

While we cannot of course be blind to the power relationships - over women and slaves - that those men of antiquity who practiced "ascesis" were involved in, what we should take from this, or rather what this opens up the possibility for thinking about, is the idea of practicing voluntary inservitude through a kind of ethical self-discipline; as I would put it, a discipline of indiscipline. As La Boétie perceived, our susceptibility to the domination of another was a kind of weakness, a moral sickness, a wayward and inexplicable desire, born of habit or induced through the false promise of riches and favors. Therefore, in order to be free, we must find a way of mastering and controlling

31. M. Foucault, “The Ethics of the Concern for Self as a Practice of Freedom”, p. 285.

32. Ibid., p. 284.

33. We have to remember that in ancient Greek philosophy, the tyrant is always a figure of great weakness and instability rather than strength; he becomes intoxicated with his own appetites to the degree that he has completely lost control over himself. For instance, in the dialogue between Socrates and Adeimantus in Plato's Republic (Book IX) Socrates proposes that: 'He who is the real tyrant, whatever men may think, is the real slave, and is obliged to practice the greatest adulation and servility, and to be the flatterer of the vilest of mankind. He has desires which he is utterly unable to satisfy, and has more wants than any one, and is truly poor, if you know how to inspect the whole soul of him: all his life long he is beset with fear and is full of convulsions, and distractions, even as the State which he resembles..." (Plato, The Republic, translation by Benjamin Jowett, The Project Gutenberg http://www.gutenberg.org/files/150/150.txt). 
such tendencies. We must, he would say, rediscover our will. And this can only be done, as Foucault shows, through these kinds of ethical practices of self-discipline. So we must be disciplined into freedom, not of course in Rousseau's sense of being forced to free - which imposes a rational ideal that coincides with the community will — but rather a kind of self-discipline that one fashions for oneself and freely imposes upon oneself. But this does not confine it to a liberal individualism: as both La Boétie and Foucault recognize, the release from voluntary servitude can only be practiced associatively, each in relation to others. It implies, above all, a micro-politics of relations.

So freedom as a release from our voluntary servitude is a discipline, an art; something that is learnt, that one learns from others and teaches oneself; something that is fashioned, worked on, patiently elaborated, practiced at the level of the self in its relations with others. It is a work on our limits, both external and perhaps more importantly internal. But freedom is our ever-present possibility and, indeed, as La Boétie and Foucault teach us, our ontological condition, our point of departure. This is, I would argue, the only way to makes sense of Foucault's critical or philosophical attitude: "I continue to think that this task requires work on our limits, that is, a patient labor giving form to our impatience for liberty." ${ }^{34}$

34. M. Foucault, "What is Enlightenment?", in Rabinow, P. (ed.), Ethics: Essential Works of Foucault 1954-1984, vol. 1., Penguin, London, 2000, p. 319. 